\title{
Scope, Possibility and Risks in Hydropower Development in the North East Region of India
}

\author{
Sharad K. Jain
}

Sharad K. Jain

Abstract: The North Eastern Region (NER) of India has immense untapped hydropower potential which can be an excellent source of electricity for India. Hydropower development is also expected to trigger overall growth of the region and improve infrastructure. Hydropower potential of NER should be exploited through an optimal mix of runof-river and storage projects. This paper discusses the prospects, possibilities and practical aspects of hydropower development in this region.

Key words: Hydropower development, North East Region, potential, risks, India

\section{Introduction to North East Region of India}

The North Eastern Region (NER) of India comprising the states of Arunachal Pradesh, Assam, Manipur, Meghalaya, Mizoram, Nagaland, Tripura and Sikkim covers a total area of 0.262 million sq. km which is $7.97 \%$ of the country's total geographical area. It is one of the most thinly populated regions of India, with about 46 million people, representing about $4 \%$ of India's population. About $65 \%$ of the land mass of NER comprises of hills; it has plains on both sides of the Brahmaputra River which are not much higher than sea level. This region has enormous bio-diversity. The terrain coupled with heavy rainfall in the tune of 2000-4000 $\mathrm{mm}$ causes floods in the valleys and water scarcity in the hills. Despite rich natural resources and biodiversity, the incidence of poverty is high in NER.

The region is of strategic importance for India because nearly $90 \%$ of its borders form India's international boundaries. It shares the northern boundary with China, South-west with Bangladesh, North-west with Bhutan, and East with Myanmar. The MacMahon line separates North East India from Tibet. This region is connected with the rest of India through a narrow corridor (popularly called the "Siliguri Neck" or the "Chicken's Neck") in North Bengal, having an approximate width of $33 \mathrm{~km}$ on the eastern side and $21 \mathrm{~km}$ on the western side.
Lake. Here the river is called Tamchok Khambab Kangri. Many snowfed streams join the river from the passes. In Tibet, the river is known as the Tsangpo; it flows into India as the Siang (or Dihang), and empties into the Bay of Bengal after traversing Bangladesh. The river traverses a distance of 2,880 km through China, India, and Bangladesh.

The Brahmaputra basin lies between $23^{\circ} \mathrm{N}$ to $32^{\circ} \mathrm{N}$ latitude and $82^{\circ} \mathrm{E}$ to $97^{\circ} 50^{\prime} \mathrm{E}$ longitude. The part of the Tibetan plateau falling under the basin has elevations varying from 3,000 to $5,000 m$ and is dotted with numerous glaciers. Figure 1 shows the Brahmaputra and Barak (Meghna) basins. The culturable area of the basin is $12.15 \mathrm{M}$-ha.

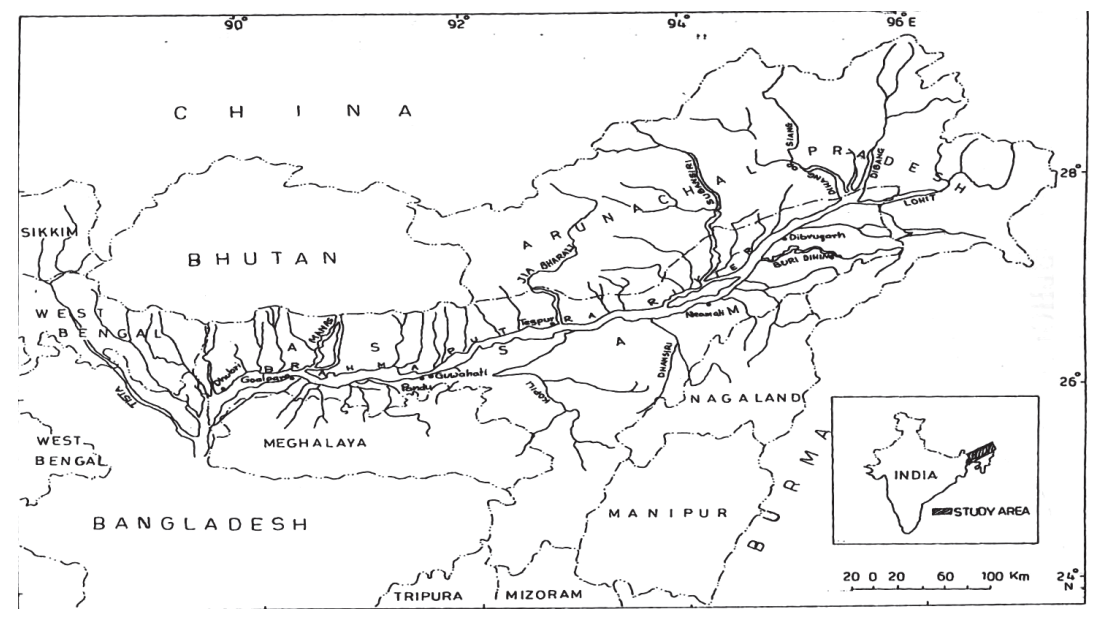

Figure 1. The Brahmaputra and Barak (Meghna) Basins (Source: Singh et al 2004).

\section{Water and Hydropower Resources of NER Water Resources of NER}

The Brahmaputra is a major international river with a drainage area of $580,000 \mathrm{sq} . \mathrm{km}, 50.5 \%$ of which lies in China, 33.6\% in India, 8.1\% in Bangladesh, and 7.8\% in Bhutan. Bhutan's 96\% area falls under this basin although the main river does not flow through Bhutan. The source of the Brahmaputra River lies in the Kanglung Kang Glacier near the Kailash range of Himalayas located in the south-western part of the Tibetan plateau at an elevation of $5300 \mathrm{~m}\left(82^{\circ} 10^{\prime} \mathrm{E}\right.$ and $\left.30^{\circ} 30^{\prime} \mathrm{N}\right)$ near the Konggyu Tso
The Brahmaputra basin in India is shared by Arunachal Pradesh (41.9\%), Assam (36.3\%), Nagaland (5.6\%), Meghalaya (6.1\%), Sikkim (3.7\%), and West Bengal (6.5\%) (Mahanta 2006). In India, the valley is $640 \mathrm{~km}$ long and its width varies from $64 \mathrm{~km}$ to $90 \mathrm{~km}$. The valley is bounded in the north by the high Himalayan ranges, in the east by the Patkai hill ranges, in the south by the lower (Assam) hill ranges and in the west, it is contiguous with the plains of Bangladesh. The southern (Assam) mountainous region of the basin is comprised of parts of the Naga hills, Mikir hills, North Cachar hills, 
Khasi hills and Garo hills. Figure 2 gives a view of the Lohit River, a tributary of the Brahmaputra.

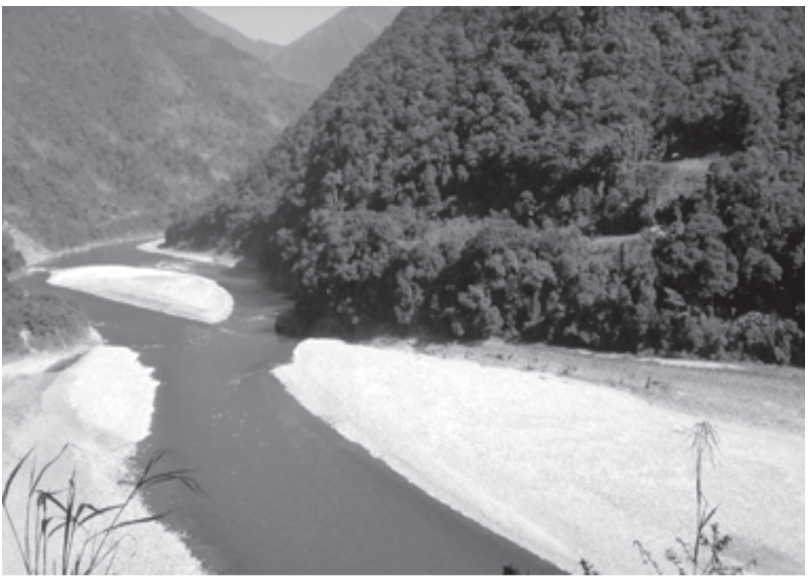

Figure 2. The Lohit River, a Tributary of Brahmaputra.

The average annual rainfall in the basin ranges from 100 to $400 \mathrm{~cm}$, most of which occurs during the monsoon months of June to September. Mean annual rainfall (excluding Bhutan and Tibet) for the basin is $230 \mathrm{~cm}$, maximum discharge of Brahmaputra river at Pandu (Assam) is 72,794 $\mathrm{m}^{3} \mathrm{~s}^{-1}$ and the average annual suspended load during flood at Pandu is $4 \times 10^{8}$ metric tons. Mean annual flood discharge at Pandu (Assam) is $51,156 \mathrm{~m}^{3} \mathrm{~s}^{-1}$. Mean monsoon flow at Shigatse (Tibet) is $507 \mathrm{MCM}$ and at Pasighat (India), it is 3979 MCM. Brahmaputra has an average annual discharge of 19,820 cumec and an average annual sediment load of 735 million metric tonnes. NER is subject to frequent flooding and soil erosion.

\section{Hydropower Resources of NER}

From a meager 1,362 MW at the time of independence, the installed capacity in the country has risen to 202,979 MW (end of May 2012). Despite this growth, all the power regions of the country have been facing widespread shortages for some years. The power shortage in NER is about $11 \%$.

The Central Electricity Authority (CEA) has assessed the hydropower potential of the country at 84,040 MW at $60 \%$ load factor from a total of 845 projects. The Brahmaputra basin has a potential of $34,920 \mathrm{MW}$ from 140 identified schemes. The potential developed in NER region is only $1.91 \%$. Even after completion of the hydro schemes under construction, the potential exploited in the region would be about $10 \%$. Thus a large potential will remain undeveloped in NER which will play a vital role in hydropower development of the country.

India's present (June 2012) hydropower installed capacity of $39,060 \mathrm{MW}$ is $26 \%$ of national hydropower potential. In NER, hydro contributes about half of the total installed capacity (2,330 MW). Figure 3 shows the dam at Kopili which is an existing project of $200 \mathrm{MW}$ capacity. The consumption of electricity in NER is largely in the domestic and commercial sectors (45\% of total). The industrial consumption is less than $1 \%$ of the total industrial consumption of the country.

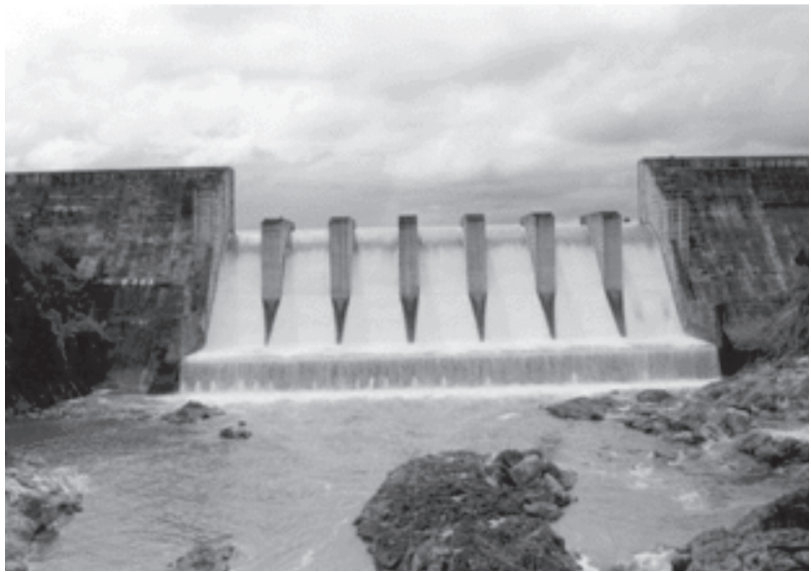

Figure 3. A View of the Kopili Project.

The Government of India launched the 50,000 MW hydroelectric initiatives in May 2003. Under this, NER had 72 schemes with installed capacity of 31,925 MW which constituted about $64 \%$ of the total capacity involved. Arunachal Pradesh alone had 42 schemes with installed capacity of about 27,300 MW. Development of hydropower potential in NER will open growth prospects and provide an opportunity to improve the well being of the people. It will also make substantial contribution to national economy.

\section{Why to Develop Hydropower Resources of NER?}

There are several reasons why the hydropower resources of NER should be developed. Energy is a crucial input in economic development and due to various reasons, the country is facing large shortage of energy - overall as well as peaking. Electricity generated in NER can meaningfully help in overcoming the shortage. Hydropower sector is one of the best options for economic development in NER provided the projects are designed and constructed after properly taking care of social and environmental concerns. Multi-purpose projects will give additional benefits by way of flood control, navigation, and augmentation of lean season flows.

Many schemes from NER are economically very attractive. According to Rao (2005), NER has 30 schemes with an installed capacity of 23,286 MW whose first-year tariff is less than Rs. 2.50 per kW-hr. About half of these schemes (16 schemes, 18,366 MW) have first-year tariffs less than Rs. 2.00 per kW-hr. Table 1 shows the number schemes in different categories and installed capacities. Note that the calculations were based on Central Electricity Regulatory Commission tariff notifications prevalent around 2005. Anyway, the substantial block of economic hydro potential available in NER merits serious action-oriented consideration to help meet the future power needs of the country.

Large-scale development of hydropower potential of NER to overcome the shortage of energy in the country will not be justified unless a part of this energy is utilized in the region. The native power demand in NER is very low. It is only about $2 \%$ of the total demand of the 


\begin{tabular}{|c|c|c|c|c|c|c|c|}
\hline \multicolumn{2}{|c|}{ Tariff < Rs. 2.50} & \multicolumn{2}{c|}{ Tariff Rs. 2.50-3.00 } & \multicolumn{2}{c|}{ Tariff Rs. 3.00-3.50 } & \multicolumn{2}{c|}{ Tariff > Rs. 3.50 } \\
\hline No. of Schemes & IC (MW) & No. of schemes & IC (MW) & No. of schemes & IC (MW) & No. of schemes & IC (MW) \\
\hline 30 & 23,286 & 8 & 945 & 10 & 2,368 & 24 & 5,326 \\
\hline
\end{tabular}

IC: Installed capacity.

Table 1. Preliminary Feasibility Reports: Breakdown of Schemes by Tariff (Source: Rao 2005).

country. Among the states of NER (Table 2), Arunachal Pradesh, is likely to have an estimated peak demand of less than 200 MW by 2016-2017. Special efforts are needed to encourage industrialization which will create employment and growth opportunities in the region. Improved life style and social growth would enable the inhabitants of NER to view hydropower projects as an instrument for regional benefit, not merely for export to the others outside the region.

\begin{tabular}{|l|c|c|c|c|}
\hline \multirow{2}{*}{ Region } & \multicolumn{2}{|c|}{$\begin{array}{c}\text { Energy Requirement } \\
\text { (GWh) }\end{array}$} & \multicolumn{2}{c|}{ Peak Load (MW) } \\
\cline { 2 - 5 } & $\mathbf{2 0 1 1 - 1 2}$ & $\mathbf{2 0 1 6 - 1 7}$ & $\mathbf{2 0 1 1 - 1 2}$ & $\mathbf{2 0 1 6 - 1 7}$ \\
\hline $\begin{array}{l}\text { Arunachal } \\
\text { Pradesh }\end{array}$ & 423 & 588 & 136 & 189 \\
\hline Assam & 7,604 & 10,870 & 1,423 & 2,034 \\
\hline Manipur & 1,672 & 2,679 & 406 & 651 \\
\hline Meghalaya & 1,410 & 2,071 & 293 & 430 \\
\hline Mizoram & 838 & 1,331 & 217 & 345 \\
\hline Nagaland & 555 & 790 & 141 & 200 \\
\hline Tripura & 1,559 & 2,427 & 396 & 616 \\
\hline $\begin{array}{l}\text { Region with } \\
\text { Sikkim }\end{array}$ & 14,373 & 21,161 & 2,850 & 4,249 \\
\hline
\end{tabular}

Table 2. Long-term Electricity Forecasts by NE State (Source: Draft National Electricity Plan, CEA 2004).

Construction of hydropower projects in NER would also lead to development of infrastructure (roads, communications, and electricity supply to remote areas), industrialization, and improvement in living standards. It would be necessary to identify industries that could be set up in the region to utilize the cheap electricity. Preferably, these industries should be based on local resources and should not damage the environment. Further, adequate transmission network should be set up in the region to take electricity to the people. For the hydropower projects funded by the central government, the home state receives free power @ 12\% of generation as royalty. This power can be used to electrify uncovered areas or it can be sold to provide additional revenue to the state government. Arunachal Pradesh would be receiving substantial free power if the identified projects are constructed.

Since water is abundant in NER, some of it can be beneficially transferred to the other parts of the country. There is a proposal to transfer water from the Brahmaputra basin to the Ganga by a canal known as the Manas- Sankosh- Teesta- Ganga Link Canal. It envisages diversion of water from a tributary, the Manas River to the Ganga River. However, such proposals are not likely to materialize in the near future.

\section{How to Prioritize Projects in NER?}

Since the first step in constructing a project is preparation of a Detailed Project Report (DPR), a program for surveys, investigations and preparation/ updating DPRs should be initiated. As environmental, submergence, rehabilitation and resettlement issues, etc. are minor in ROR projects, such projects (included in the master plan) may be taken up for implementation on priority basis. Meanwhile, further data collection and studies for integrated development of water resources to maximize the benefits from multiple uses of water may be completed. The lower Brahmaputra basin is subject to frequent floods and these can be adequately mitigated only by storage projects. Further, storage schemes should not be given up or converted into ROR schemes unless there are adequate technical and social reasons.

Tariffs to consumers should be one of the key considerations to prioritize projects. This is important because in case of NER projects, the cost of transmission of power to the regional grid will be substantial since power demand centers are far from the projects. Hence, long transmission lines would have to be constructed and such costs should also be factored in while assigning priority to projects.

Construction of hydropower projects requires detailed and rigorous investigations involving field and office work. Many times, the desired time and efforts are not put in and this results in delays in obtaining clearances and surprises during construction. Efforts should be made to overcome these bottlenecks. It would be necessary to carry out a cumulative impact assessment study to understand and identify long-term and shortterm impacts of all the projects in a basin. Such a study will help in deciding which projects should be taken up.

\section{Issues in HP Development in NER}

Difficult access, remote locations, lack of infrastructure, small number of working months, and insurgency/law and order problems are the first set of problems which hamper hydropower development in NER. The next set of major problems involve difficulty in field investigations (which minimize geological surprises); land acquisition; rehabilitation and resettlement of projectaffected populations; social and environmental issues; submergence of forests; impact on the river ecosystem; safety of dams in a seismically active zone; contractor related problems, etc. Investigation of projects can also be delayed by legal issues, as in the Subansiri project.

Poor infrastructure (chiefly transport networks) is a bottleneck in the construction and management of hydro-projects. China, for instance, constructs highways connecting hydro-projects as the initial steps 
in construction phase. This saves considerable time, wear and tear, and hardships. This approach needs to be adopted in India also. If good quality roads are constructed up to the project site in the initial stages, the returns are immense.

Of late, the private sector is being roped in to accelerate the construction of hydropower projects. However, some private sector companies with inadequate experience, background, resources, and interest in hydropower development have been allotted projects but are unable or unwilling to take up these. Rather than accelerating hydropower development, as was the basic intention, this has resulted in delays. Therefore, projects should be allotted only to the companies having adequate experience, resources, and interest in hydropower development, and there should be some mechanism to ensure that the allotted projects are completed in time (of course the requisite clearances should also be given promptly).

\section{Should Storage Projects be Developed in NER or not?}

The potential hydropower assessment of NER is $34,900 \mathrm{MW}$ (at 60\% load factor) assumes that storage based schemes will be developed in the Siang or Dihang (the main stem of Brahmaputra), Subansiri, Lohit, Dibang basins and other places. These projects were expected to generate power as well as give flood control benefits. In all likelihood, these projects appear to be quite difficult now on account of submergence issues and the reluctance of the concerned State Governments to go ahead with the project. These projects are likely to be replaced by a series of small dams or ROR projects. The Lower Subansiri Project ( 8 x 250 MW), the lowermost site in the Subansiri basin - at the same place where earlier a high dam was proposed- has been taken up for construction by the National Hydroelectric Power Corporation (NHPC) as a ROR scheme. It is likely to be commissioned by December 2012. The developments in the Dihang basin have also undergone modifications as cascade development.

On account of monsoon climate, Himalayan rivers exhibit strong seasonality; flows during the winter months (December to February) are very low and these are extremely high during the monsoon months (June to September). A storage reservoir can regulate flows and generate power in accordance with the demand. A ROR project will generate power as per the variation of stream flows. Hence, a large quantity of energy would be available during the monsoon and much smaller in winters. Thus the advantages of storage projects should be given due weight in the preparation of basin plans.

There are concerns in the development of hydropower, particularly in respect to the projects that involve construction of large dams. The World Commission on Dams (WCD 2002) has concluded that "dams have made an important and significant contribution to human development, and benefits derived from them have been considerable ... In too many cases an unacceptable and often unnecessary price has been paid to secure those benefits, especially in social and environmental terms, by people displaced, by communities downstream, by taxpayers and by the natural environment". WCD also observed that there is a lack of equity in the distribution of benefits.

Dams do impact the river ecosystems in many ways: they block rivers and impede the passage of nutrients, silt, fish and other aquatic organisms; they impact fish migration and spawning; they cause submergence of forests and villages and displacement of population. But if properly planned and managed, most of the ill effects of the dams can be overcome. During construction and operation of a hydropower project, all activities and impacts should be monitored and executed according to an environmental management plan agreed by the various stakeholders.

As per the provisions of the Electricity Act (2003), the CEA is to satisfy itself before giving concurrence to a proposed hydropower project that it does not "prejudice the prospects for the best ultimate utilization of the river or its tributaries and the ultimate development of the river or its tributaries for power generation is consistent with the requirements of drinking water, irrigation, navigation, flood control and other public purposes". Thus the CEA has a crucial role in guiding the optimal development of the river basins. Needless to state, once a storage scheme is converted to a ROR scheme, the benefits foregone from the multipurpose use of water, flood control, as well as reduced hydropower generation cannot be recovered. It is, therefore, necessary that the trade-offs in ROR vs. storage projects are determined and the basin planning is carried out so that there is no significant loss of power potential.

\section{Rehabilitation and Resettlement}

Many hydropower projects in NER would be constructed in the tribal areas and are likely to result in submergence of villages, relocation of population, loss of forests and bio-diversity, and disruption of community networks. This is a serious issue which needs to be addressed with a human-centric approach. It would be necessary to evolve a liberal policy on resettlement and rehabilitation specifically tailored to ground realities and socio-economic conditions of NER.

Successful development of hydropower should improve living conditions of the affected communities and provide equitable distribution of project benefits. Local and traditional knowledge of communities should be utilized in project planning, construction, and operation. The planning process for hydropower development should ensure that adequate consultation is done with the community and institutional stakeholders to identify the impacts on the community and appropriate mechanisms for impact mitigation are put in place. A comprehensive resettlement plan should have the consent and acceptance of the community, and 
provide sustainable long-term solutions to protect the livelihoods and social networks. One may note recent incidents related to land acquisition in India and the unpleasant situations created due to resistance by the land owners.

If people find that relocation will improve growth opportunities, they will support development activities such as hydropower projects. Managing issues related to rehabilitation \& resettlement is difficult because it requires balancing diffused interests against concentrated interests. It asks those affected by a project to trade off today's certainties for tomorrow's uncertainties. This will require far-reaching changes in institutions to mobilize trust and involve the communities as partners in progress.

\section{Power Transmission Issues}

Since the power generated from the projects in NER would be much more than the demand in the region (in the foreseeable future), energy would have to be exported to other parts of the country. To that end, long distance high-capacity transmission lines would have to be built. Cost of transmission of power to the load centers could be substantial (say more than Rs. 2.oo per kWh). Moreover, the transmission lines would have to pass through the Siliguri corridor but this is not likely to be a serious handicap in the near future. With the establishment of a national grid, there will not be much problem in the transmission of power to other parts of the country after it reaches the eastern power grid but the cost of power transmission up to the eastern grid would have to be factored in the project costs.

The transmission system for evacuation of power from the Kameng (6oo MW) project is estimated at Rs. 11,000 million, about $50 \%$ of the generation cost of the project. Similarly, in the case of the lower Subansiri (2,000 MW), the transmission cost would be about Rs. 100 billion (Rao 2005). These costs would also rise with time.

\section{Institutions for Project Implementation}

There are a number of organizations at the Centre and State levels working in the areas of power and water resource development in NER. However, in view of the complex issues involved in water and power development, the government may consider establishing, say, North East Water Resources Authority for the integrated development of NER water resources. This authority will take action to generate electricity, implement effective flood control, develop irrigation, and also infrastructure. Such actions could transform the region from an underdeveloped to a developed region. This institution can also take up research studies for finding solution to NER problems. In view of this and experience gained so far, the creation of a new empowered organization is necessary for water resource and hydropower development in NER. According to WB (2007), resources-led growth must be accompanied by institutional reforms and policies that are conducive to broad-based development.

The first task of such an organization should be to create a modern database and prepare a master plan for the coordinated development of the various projects along with infrastructure development, and policy for resettlement and rehabilitation, and land acquisition. The master plan should have the concurrence of State Governments so that there are no hurdles in its implementation. The implementation of the schemes should be a distinct activity, and it is desirable to separate it from the regulatory and superintending functions. The decisions of such an authority in all matters under its purview should be binding on all the agencies involved in planning, development, construction, and operation of plants in the basin. An organizational setup along the lines of the Damodar Valley Corporation in India or the Tennessee Valley Authority in the USA could be considered.

\section{International Issues}

Most rivers of NER are transboundary and optimal development requires international cooperation. There is excellent cooperation between India and Bhutan regarding development of hydropower. The Tala run-ofriver hydroelectric project (1020 MW) is the biggest joint project between India and Bhutan, and it generates 4,865 million $\mathrm{kWh} / \mathrm{yr}$ of energy. Other projects constructed in Bhutan with Indian assistance include Chukha (336 MW) and Kurichu (45 MW). Surplus power from these projects is exported to India.

There are possibilities for utilizing the U-bend (or the "Big Bend") in the Tsangpo River between Tibet and Arunachal Pradesh in India for large-scale hydropower development. A drop of about 3,000 meters is available where the Tsangpo flows at an altitude of 3,600 meters and descends to Gelling in Arunachal Pradesh, which could be utilized for generation of a very large amount of power. This possibility has been identified but no feasibility study has been initiated so far.

The Tipaimukh multipurpose project on the Barak, proposed at the tri-junction of Manipur, Mizoram, and Assam, seems to have raised needless apprehension in Bangladesh that the project would dry up the Barak River and cause monsoon flooding in the Sylhet region. With a specific flood cushion, this project would provide substantial relief to flood-prone areas in the Cachar Valley in India and the Sylhet region in Bangladesh. In fact, Tipaimukh was the first flood moderation study suggested by Bangladesh after the Indo-Bangladesh Joint Rivers Commission was established in 1972. But subsequently, their view about this project has undergone a sea-change.

\section{Risks in Development of Hydropower in NER}

There are two external risks in the development of water resources of the NER:

1. Large scale upstream developments by China which may have significant impact on water availability and 
its distribution in India.

2. Reduction in flow due to impacts of global warming and climate change - decline in precipitation and recession of glaciers.

These are discussed below:

\section{Impacts of Upstream Developments in China}

Reports indicate that China may be constructing some projects in the Brahmaputra basin in Tibet. The population of China is more concentrated in the northern part of country but the rivers in the north have comparatively smaller flow, larger seasonality and remain frozen for long periods. The rivers in the northern region have about $15 \%$ of the water of the country whereas the population is nearly half. In contrast, the southern region has large water potential.

Until about the year 2005, water demand in China was less than the availability but thereafter, the demand has overtaken the supply and by the year 2030, the projected demand is likely to be about $800 \mathrm{BCM}$ against the supply of 750 BCM. Since water scarcity is mainly concentrated in the North, China has launched a massive project to divert the waters of the Yangtze River to the North. With the track record of taking up massive civil engineering projects, at times ignoring any environmental concern, it is not surprising if the Chinese Government decides to construct projects to harness the waters of the Brahmaputra River.

\section{China may Construct Three Types of Projects}

a) Run-of-River Projects: A run-of-river (ROR) project generates hydroelectric energy from the flow of a river as it occurs and there is no significant storage of water. Hence, for India, the impact of such a project on the flow of the Brahmaputra will be negligible.

b) Storage Projects: A storage based project will be able to store and regulate stream flows for, say irrigation and hydropower generation. It is estimated that in the lean season, the flow in Arunachal Pradesh would be about 15 BCM. Hence, if China stores water in the lean season, the flow in the river will drop. This will have an impact on hydropower generation in the lean season and on withdrawals for irrigation and other uses.

c) Water Diversion Project: A water diversion project (with or without storage) would result in reduced flows of the river in the Indian part. Consequently, some proposed hydropower projects in India may become unviable and the benefits from some others may dramatically reduce. Large reductions in flows during lean season will have detrimental impacts on bio-diversity and uses of river water. The impact of diversion will depend on the quantity and time distribution of the diversion.

\section{Impacts of Climate Change}

Global warming and climate change may lead to less flow if precipitation declines. China will not construct a large project if it is likely to face difficulties due to climate change. However, it is difficult to make any prediction in the absence of adequate and reliable data. India should try to get hydro-meteorological and other relevant data for the Chinese part of the basin and commission some studies so that the various scenarios of climate change and the impacts could be studied. This will also help in taking better decisions for the development of hydropower in NER.

\section{Conclusions}

The immense untapped hydropower potential of the NER is an excellent source of electricity that can contribute significantly to meet the current and future power demands of India. Identified schemes should be taken up for implementation on priority basis. Hydropower development will also trigger overall growth of the region and improvement of infrastructure. Increased availability of electricity could accelerate economic progress in the region.

The immediate need for the development of the region's hydro potential is to help meet national power demand through export of power to other regions of the country. The cost of power transmission to load centers would be substantial in the initial years, making power more expensive at destination. Access to low-cost longterm funds and a national transmission tariff are possible options to resolve the problem.

The hydropower potential of the region should be exploited through a mix of run-of-the-river and storage projects to maximize benefits and minimize adverse environmental impacts. Storage projects would provide higher firm power, regulated energy, and multipurpose benefits of flood control, irrigation, navigation, etc. Initial attempts should be to develop those projects that have less resistance and give quick return. Small and mini hydro projects should also be developed sideby-side. For integrated and optimum development of the resources of NER, a coordination mechanism is essential. An empowered authority to formulate policies for development, funding, construction and operation of infrastructure projects may be set up to accelerate the development of the NER.

Sharad Kumar Jain is a scientist at the National Institute of Hydrology, Roorkee, India with research, development and teaching experience of nearly 30 years in the field of water resources. His research interests include Surface Water Hydrology, Water Resources Planning and Management, Hydropower, and Impact of Climate Change. He has also been involved in many research and consultancy projects. During Apr. 2009 - Apr. 2012, he was NEEPCO Chair Professor at IIT Roorkee. He was a Post-Doctoral fellow at the National Research Institute for Earth Science and Disaster 
Prevention (Japan) and served as Visiting Professor at the Louisiana State University, USA for one year.

Sharad Jain has co-authored three books: a) Water Resources Systems Planning and Management, Elsevier, b) Hydrology and Water Resources of India, Springer, and c) Risk and Reliability Analysis: A Handbook for Civil and Environmental Engineers, ASCE. He has also edited five books and published nearly 200 papers in journals and conferences. Dr Jain is a member of the International Board of Advisors of the Journal of Hydrologic Engineering, ASCE; and member of the Editorial Board of the Hydrological Processes Journal (Wiley-Blackwell). He is a Fellow of the Institution of Engineers (India), Indian Water Resources Society, and Indian Association of Hydrologists.

Corresponding address : s_k_jain@yahoo.com

\section{References}

Goswami, D.C., 1985, Brahmaputra River, Assam, India: Physiography, basin denuadation, and channel aggradation. Water Resources Research, 21(7), 959978.

Jain, S.K., P. K. Agarwal and V.P. Singh, 2007, "Hydrology and Water Resources of India", Springer Publishers, The Netherlands.

Kusre, B. C., and S. C. Patra (2005). Water for life in
NE region: River Systems, Water Demands, Floods and Water Logging. Proceeding of 11th National Water Convention, organized by National Water Development Agency at New Delhi on 11th May 2005.

Mahanta, C., 2006, Water Resources in the Northeast: State of the Knowledge Base. Background Paper No. 2, Ministry of Development of North Eastern Region, Downloaded from the website http://mdoner.gov.in.

Rao, V.V.K., 2005, Hydropower in the Northeast: Potential and Harnessing Analysis, Background Paper No. 6, Ministry of Development of North Eastern Region, Downloaded from the website http://mdoner.gov.in.

Singh, V.P., N. Sharma and C.S.P. Ojha, 2004, The Brahmaputra Basin Water Resources. Water Science and Technology Library, Kluwer Academic Publishers, Dordrecht.

WB, 2007, Development and Growth in Northeast India: The Natural Resources, Water, and Environment Nexus. Strategy Report No. 36397-IN, The World Bank, Washington DC.

WCD, 2000, Dams and Development: A New Framework for Decision-Making. The Report of the World Commission on Dams, Earthscan Publications Ltd, London.

\section{CALENDAR OF EVENTS - WATER/SANITATION}

19-23 August, 2012: Stormcon-The North America Surface Water Quality Conference and Exposition 2012. Location: Denver, CO, USA. More info: http://www.stormcon.com/

26-31 August, 2012: World Water Week. Location: Stockholm, Sweden. More info: www. worldwaterweek.org

16-21 September, 2012: IWA World Water Congress and Exhibition 2012. Location: Busan Korea. More info: www.awwa.org

29 September-3 October, 2012: 85th Annual Water Environment Federation Technical Exhibition and Conference. Location: New
Orleans, Louisiana, USA. More info: www.weftec. org.

9-10 October, 2012: 6th European Water and Wastewater Management Conference and Exhibition.Location:Manchester, United Kingdom. More info: http://www.ewwmconference.com

29-31 October, 2012: Water Expo China. Location: Beijing, China. More info: http://www. waterexpochina.com

4-8 November, 2012: Water Quality Technology Conference \& Exposition (WQTC). Location: Toronto, ON, Canada. Contact Email: skemp@ awwa.org. More info: www.awwa.org

\section{CALENDAR OF EVENTS - RAINWATER HARVESTING}

10-12 September, 2012: Urban Rainwater Capture: Where Technology, Regulation and Opportunity Connect (ARCSA Annual Conference). Location: Raleigh, NC. USA, More info: http://www.arcsa.org

\section{CALENDAR OF EVENTS - IRRIGATION}

23-27 September, 2012: 11th International Drainage Workshop (IDW). Location: Cairo, Egypt. Contact E-mail: encid@link.com.eg. More info: http://www.encid.org.eg/idw11

11-13 December, 2012: 4th International
Conference' on Sustainable Irrigation and Drainage. Location: Adelaide, Australia. Contact Email: bcopland@wessex.ac.uk. More info: http:// www.wessex.ac.uk/12-conferences/sustainable=irrigation-2012.html 